\title{
XXII. Fossil bones on the coast of East Norfolk
}

\section{Mr. Richard Taylor}

To cite this article: Mr. Richard Taylor (1822) XXII. Fossil bones on the coast of East Norfolk, Philosophical Magazine Series 1, 60:292, 132-135, DOI: $10.1080 / 14786442208652803$

To link to this article: http://dx.doi.org/10.1080/14786442208652803

曲 Published online: 29 Jul 2009.

Submit your article to this journal $2 \pi$

Џ Article views: 2

Q View related articles $₫$ 
Your Committee particularly recommend, as indispensably necessary for coconony as well as safety, according to the opinions of all the witnesses who were examined to this point, that a professional engineer should be employed to reside constantly'at Holyhead, to superintend the machinery and inspect the engine-keepers. And xalso that each vessel should be supplied with an extinguishing fire-engine, and with two large boats in addition to the ordinary ship's boat.

From the great advantages which may be derived from revolving furnaces, your Committee feel anxious that a proper experiment should be tried to ascertain whether they can be used in place of the common fire-places.

[The Report concludes with some suggestions relative to the management and fares of the steam-boats between Holyhead and Dublin, as well as the Custom-house arrangements, docks, roads, and Post-ofhee regulations.]

\section{Fossil Bones on the Coast of East Norfolk. By} Mr. Richard Taylor.

\section{To the Editors of the Philosophical Magazine and Journal.}

Gentringn, - I IEG to communicate an extract from some geological memoranda made during an excursion a few days ago along the Norfolk coast, from Cromer southward;-ny object being chiefly that of pointing out the localities of an extensive stratum of o teological renains.

Throughout the course of the cliff's which form the eastern boundary of this county aguinst the German Ocean, from Happisburgh to the north of Cromer, may be traced, at intervals, along the base of the clay clifs, a remarkable stratum containing an abundince of fossil wood and the bones of large herbivorous animals nineralized by iron. The thickness of this singular bed bos not exceel two feet, and frequently not more than one. It varies in its material. from a red ferruginous sand to an ochreous coarse gravel cenented by iron, and often divided inio seita by a coarse fermginous kind of crystallization, accompaned by thin, fatened, and circular cakes of very hard argillaceous red-coloured stone: others are spherical, from the size of a hazel-nut to that of a hen's egg, and resembie the seed-ressels figured in the first volume of Parkinson's Organic Remains.

The vicinity of the stratum which I shall proceed to describe, is always indicated by the abundance of these stones, which are washed to the base of the cliff's, and, being too hard 
to be readily injured by attrition, are sometimes accumulated in considerable quantities. Many of the nodules having been split into laminæ by the operations of the air, moisture or frost, are again united by a cement of hard ferruginous sand; and in this state some of the fossils and bones are discovered.

The most numerous organic substances here are those of vegetable origin, in various degrees of preservation and mineralization, from the state of black and rotten peat wood to that of a ponderous iron-stone, somewhat flattened by pressure, as I believe is the case with all fossil wood. When any portion of this stratum is exposed horizontally on the beach, fragments of oak-wood several feet long are often uncovered by the waves. It is probable that the bed containing this wood extends along the coast, below the level of the sea, much more to the south than Happisburgh ; for large masses in all stages of preservation are continually thrown up on the beach as low down as Caister, Winterton, and Palling. We should eren be correct in stating it to be an extension of the well-known stratum at Watton-cliff' and Harwich. The part of the Norfolk coast where it is most conspicuous, is-at Overstrand, about three miles south of Cromer. Here some small springs of chalybeate water ooze out of the ferruginous bed before noticed, imparting to the pebbles of the beach and to the waters left by the tide a strong tinge of bright brown or red. Here and there are scattered heavy nodules of radiated pyrites, which are brilliant when broken, and of the colour of brass; and a strong sulphurous smell is emitted, particularly in warm weather. Some pieces of iron thickly incrusted with ferruginous sand and shingle were completely metallic at the core.

A few of the flattened stones have casts and impressions of shells upon their surfaces, particularly sone species of Astarte or Venus.

But the most important amongst the organized remains here are the reliquice of land animals, of which the elephant and the deer are the most conspicuous. A fine grinder of that which bears a close affinity to the East Indian elephant was recently detached by me from this stratum. It is ponderous and discoloured; for it is probable that iron now forms one of its chief component parts and has added much to its weight. The plates which remain are nine in number; the enanel is perfectly white, and the intermediate spaces are of a deep black: the whole length of the triturating surface is about six inches, and when perfect was originally much longer. See Plate II. fig. 2 .

Embedded with this was what I conjectured to be the upper part of the skull of an animal cqual in size to the ele- 

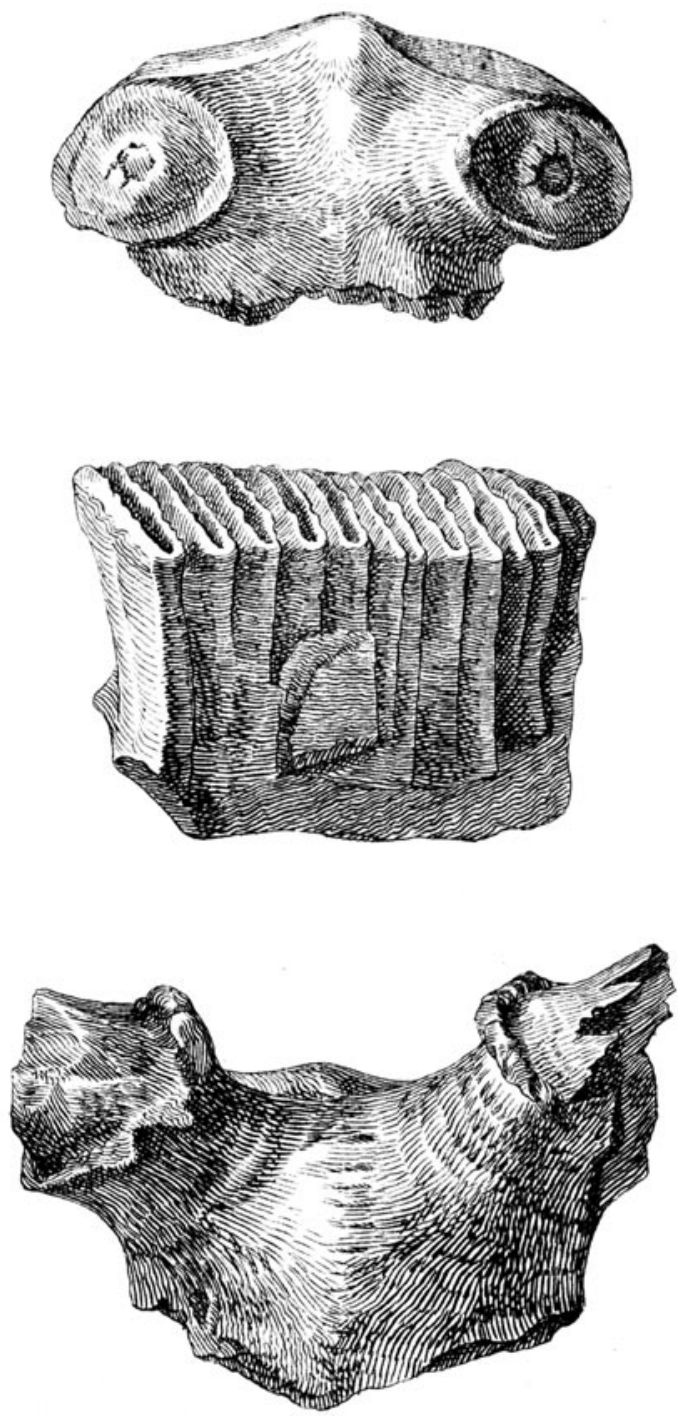

Fofsil Bones found near Cromer. 
phant. This was fifteen or eighteen inches in diameter, and upwards of three inches thick, externally black and perfectly smooth. Unfortunately this specimen was not capable of removal, except in fragments, from its having been divided into a number of pieces by the splitting into the kind of septaria and subsequent filling up with ferruginous matter mentioned before. This mass probably weighed fifteen pounds; and I regret that it was so decomposed and distorted, from these circumstances, as to render it doubtful as to the precise original shape.

Fragments of huge bones, more or less worn by attrition, according to the time in which they have been removed from their sites in the cliff, are met with on the beach. Some of them are light and cellular, but for the most part they are very heavy, deriving their weight from the iron with which they are strongly impregnated.

Nearer Cromer, embedded in the same stratum, I met with the upper part of the skull or frontal bone of an animal of the elk kind, having a portion of the horns remaining, but broken off a little above their bases. Its surface is smooth, black and shining; extremely ponderous, the forehead about six inches broad. Fig. 3 .

Another skull which much resembles this, accompanied with vertebre of land animals, I have obtained from a similar stratum of ferruginous gravel a few miles south-west of this spot, a continuation, probably, of that which is exposed in the cliff between Mundesley and Cromer. Fig. 1.

Fossil bones have long ago been noticed in the cliffs of Norfolk as occurring incidentally, for it was not known that they were stratified. Sir Thomas Browne communicates in a letter to Sir William Dugdale, in the year 1659, that the head and bones of a very large fish were discovered near the top of Happisburgh cliff; by the falling down of a part of the soil in which they were embedded.

The fossil grinder of an elephant of the Asiatic species was also found here, in 1805, by Mr. William Smith, and is now with his collection in the British Museum.

It is probable that a more extended osteological examination will lead to the discovery of the mineralized remains of other animals in this situation. At present we have added one to the many authentic instances of the remains of the stag being associated with those of the êlephant. We may add a further instance in the neighbourhood of Norwich, where the horns of stags are associated with the opalized teeth of the mastodon or mammoth and the grinders of elephants.

The stratifeat orgenic remains in the clifts of Wast Norfolk 
are buried beneath beds of blue clay, earth and sand, from 80 to 100 feet in thickness. Some of the indurated and flattened stones belonging to or immediately in contact with this stratum, contain well-preserved specimens of Astarte, Pecten, Cardium, Terebratula plicata, large Serpula, Trochus, Nucula? and a small pyritous ammonite with foliated septa.

In the clay substratum are boulders of strong dark blue clay, in which the fossils assimilate to those of the clay in the environs of London. Sharks' teeth, 'Tellina, Cardia, and Ammonites communis, have been figured in Smith's "Strata identified by organized Fossils," collected from the incurated clay nodules of Happisburgh cliff. From clay boulders at Overstrand cliff I have obtained Gryphæa with unusually thick and gibbous valves. A species of Ostrea or Gryphra is also found here remarkable for having its valves chalcedonized, and the internal cavity filled with dark-coloured silex. These shells are perfectly white, very thick and tumid, and from four to five inches long. Although I have seen many specimens, all have been considerably rounded by attrition upon the beach, and I do not know of any that have been discovered in situ and uninjured.

As these memoranda are the result of a single examination of a portion of our strata which is little known, they will, I trust, be received as such. Subsequent inquiry will doubtless add much to the geologic information here collected, and will probably occasion another communication, in some future Number of the Philosophical Magazine, from

Norwich, Aug. 14, 1829.

Richard Taylor.

XXIII. Notices respecting New Books.

Part I. of The Philosophical Transactions of the Royal Society of London, for 1822, has just appeared: the following are its contents :

I. The Bakerian Lecture. An Account of Experiments to determine the Amount of the Dip of the Magnetic Needle in London, in August 1821 ; with Remarks on the Instruments which are usually employed in such Determinations. By Captain Edward Sabine of the Royal Regiment of Artillery, F.R.S.-II. Some Positions respecting the Influence of the Voltric Battery in obviating the Effects of the Division of the Eighth Pair of Nerves. Drawn up by A. P. Wilson Philip, M.D. F.R.S. Edin. Communicated by B. C. Brodie, Esq. F.R.S.-III. On some alvine Concretions found in the Colon of a young Man in Lancashire, after Death. By J. G. Children, 